\title{
The Role of International Entrepreneurship Capability on International Performance in Born Global Firms
}

\author{
Azizallah Roudini ${ }^{1}$, Mohd. Hassan Mohd. Osman ${ }^{2}$ \\ ${ }^{1}$ Faculty of Management and Human Resources Development, Universiti Teknologi Malaysia (UTM), Johor Bahru, Malaysia; \\ ${ }^{2}$ International Business School, Universiti Teknologi Malaysia (UTM), Kuala Lumpur, Malaysia. \\ Email: azizroudini@gmail.com,m-hassan@utm.my
}

Received February 20 ${ }^{\text {th }}, 2012$; revised March $8^{\text {th }}, 2012$; accepted March $25^{\text {th }}, 2012$

\begin{abstract}
More than two decades, international entrepreneurship (IE) has come out as a distinct academic discipline, and that concentrates on firms that become international from inception or near after it. However, comparatively little is known about the international entrepreneurship (IE), its capability and what drives the international performance of these firms with early and rapidly internationalizations. Therefore, the objective of the investigation is to reveal the dimensions of international entrepreneurial capability (IEC) and its effect on international performance (IP) in born global firms. The study will give an instruction to the born global (BG) managers, vision and strategy to the policymakers, and introduce the effectiveness role of international entrepreneurship capability (IEC) on international performance.
\end{abstract}

Keywords: Entrepreneurship; International Entrepreneurship; International Entrepreneurship Capability; Born Global; International Performance

\section{Introduction}

The twenty-first century is a challenging decade for international business firms that they have become increasingly common in recent years. Although, traditionally the study of internationalization focused on large, well-established firms, but after globalizations, new and dynamic world economy changed all that and came out the born global (BG) firms or "international new ventures" (INVs) phenomenon [1,2].

On the other hand, the process of globalization has decreased the barriers of trade by advancing in transportation, technology and communication. This situation has shifted in global value chains and has driven the world to new arrangement such as lacking boundaries and the village of glob [3,4]. Therefore, it becomes possible the increasing and expansion in the number of firm international activities. Consequently, the interest of investigation has increased in internationalization of young and small companies [5-7].

The literature of the internationalization has received sizable attention over the last decades. All around the world, it has been as one of the most significant strategies of growth for entrepreneurial firms [8-13]. Moreover, Founding and maintaining a competitive advantage need the capacity to grasp opportunities by foreign markets, and it is significant for firms to be active in international marketplace [14-17].
Research on born global firm-level capability like international entrepreneurship capability is still a lack of investigations [18]. Therefore, we have still known very little about the born global firms and serious challenges that have faced with their established companies in the international marketplace [6]. On the other hand, these kinds of studies have rapidly increased in the developed countries [19-23].

Generally, there has been a question among scholars who the dimensions of international entrepreneurial capability (IEC) effect on international performance in born global firms. Thus, there is a need to gain insights into the role of international entrepreneurial capability (IEC) and understanding of its dimensions and relationship with international performance (IP). Therefore, this study will respond to those necessary needs in international business (IB) activities.

It endeavors to supply significant perception into the international entrepreneurship (IE), international entrepreneurial capability (IEC), its dimensions and international performance (IP) to reveal how the international entrepreneurial capability (IEC) transfer to international performance in international marketplace. The paper structured as follows: Firstly, The capabilities view as a growing interest theme, with complicated bundles and a multilevel phenomenon are discussed. Then entrepreneurial capabilities have introduced as an ability that enables firms 
to improve the bundles of resources, and to supply the sustained completive advantage that caused to success the firms in the international marketplace. In addition, the paper is focused attention on international entrepreneurial capability (IEC) as one of the essential capabilities in international business activities and its dimensions. Finally, the study major contributions have discussed.

\section{View of Capabilities}

In recent years, the view of capabilities of the organization has growing interest achievement in both areas of business strategy and academic research. From a the literature viewpoint the view of capabilities still is connected very nearly to the literature stream concentrated on the RBV of the firm [24]. Furthermore, the view of capabilities has been recognized as a fundamental construct by the domain of evolutionary economics. According to Nelson and Winter [25] illustrated capabilities and routines among the principal structure blocks of evolutionary theory.

The view of capabilities proposes that the capabilities affect more than resources in making possible the leveraging and deployment the resources that assistant a perform of the firms [26,27]. In addition, the capabilities construct is cited in management and technology investtigation [28], knowledge management investigation investigation $[29,30]$, the domain of business strategy research, and business history investigation.

Based on Day [30] capabilities are as complicated bundles of collective learning, skills and performance through an organizational process that confirm the functional activities of superior coordination. In another investigation, the definition of capabilities had been presented by Day [30] is the frequently wide reference [31-33]. Whereas extensively acknowledged, this definition has scrutinized for being narrow in capacity and limiting capabilities to the organizational level, functions and process.

Majority of recent investigations illustrate capabilities as spreading beyond functions and process. At many levels outside and inside the organization, they operate. A capability is a multi-level phenomenon, existing across firms, at the operational unit level and at the firm level. This is a more broad-reaching definition adopted and recommended [34,35]. Capabilities have been referred to achieve a desired goal need for a firm's capacity and to purposefully deploy a combination of resources and processes [36].

In the organizational processes, capabilities have been inserted as a compound package of skills and knowledge $[37,38]$. Firms utilize them as a crucial source of sustainable competitive advantage that obtains superior performance by leveraging their assets.
Capabilities were used as the glue that ties different resources together simultaneously and makes them possible to be spread out to gain maximum advantages in their activities [30].

\section{Entrepreneurial Capability}

The idiom “entrepreneurial capabilities” refers to an ability that acquires necessary resources to perform upon opportune moments recognized in the market or new market opportunities creation. At the inception of the venture, entrepreneurial capabilities can be crucial to success, while these capabilities become less important and relevant as the venture matures. More in a specific manner, entrepreneurial capabilities enable firms to improve the bundles of resources.

It can supply sustained completive advantage that caused to success international new venture [39]. What kinds of entrepreneurial capabilities are critical to international new venture success?

Based on the literature of entrepreneurship, it has been suggested four dimensions that can be depicted the ventures of entrepreneurial capabilities [40,41]. They are people, resources (non-human), timing and opportunity. People and resources as the first two dimensions that handle the ventures capacity toward resources by the markets with factor of strategy [42]. Timing and opportunity as the last two dimensions make it possible to deal with the ventures capabilities and maneuvering in special contexts [41]. Autio et al. have explored that with fundamental uncertainty of environment that new ventures are faced, how the future investigations in entrepreneurship might think regarding new capabilities emerge and solidify [43].

\section{The Triad Model of Entrepreneurial Capabilities}

In this section, a model of entrepreneurial capabilities is related to the literature of entrepreneurial capability reviews and reveals a comprehensive definition of the study. Past researchers have demonstrated a need to strengthen an interpretative framework that can serve as a foundation for future theory of building and testing of entrepreneurial capability [44]. Therefore, based on [45] Figure $\mathbf{1}$ presents a proposed integrative framework for responds to that need.

The triad model of entrepreneurial capabilities hints that the organizational and the personal capabilities, which form the bottom line, are two fundamental capabilities.

International business scholars have mentioned the notion of organization capabilities through interpretation of the firms increasing internationalizations [46].

On the other hand, the ontological side of entrepreneurial capability corresponds with the personal capability. 


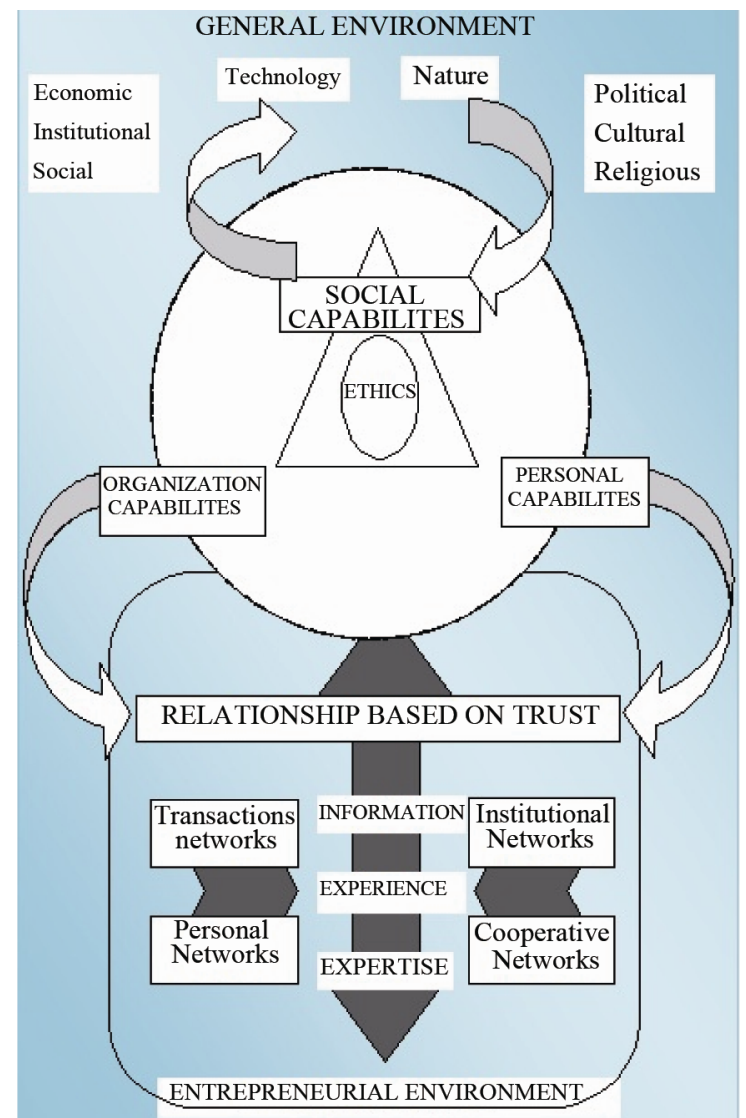

Figure 1. The traid model of entrepreneurial capabilities.

According to this view, it introduces the abilities of entrepreneurs that embedded them, and the individual exclusively has dependence on by an individual and whose incorporate [45]. The spirit of the organizational capabilities is the integration of knowledge that the scholars of management have conceptualized [26,47]. Proactive personality is the most appealing construct that has been defined as the extent to influence their environments by individual take action [48]. Personal and organizational capabilities have influenced on entrepreneurial governance and finesse because of their ethical content, in a reciprocal way. The entrepreneurs' personal capabilities have been shaped by proactive personality and entrepreneurial alertness patterns, and this caused the effective entrepreneurial societal capability [45].

Entrepreneurial social capabilities are also contingent on organizational potentialities, trustworthy strategic direction and networks, that constitute organizational capability.

Societal capabilities that are displayed at the top are the important ones. This capability settles that kind of entrepreneurship, which is acceptable and sustainable in various communications developing through time. This model is sufficient to carry all those aspects to illuminate in a straightforward way and to enable for more elabora- tion.

One of the important issues on entrepreneurship worldwide has been cultural aspect. Culture is indispensable to have in mind the difference between community-based and individual based cultures. In the western countries, the individual-based cultures have been the basic rule of the social life and the civil society has been inflounced by this culture. In the parts of eastern and southern countries, the development of entrepreneurship is linked o subduing property. Nonetheless, in these countries, the collective values have rooted from traditions and community history. These contents have stood in the way of entrepreneurship careers. For instance, in African way, the development of entrepreneurship would have required a process of individualization [49]. Collective values regulating social life, as respected codes of conduct, have been a very strong influence within civil society in some collective countries. Although they may have priority in the interests of their businesses, in these countries small businesses that have owner-managers, do not set aside fundamental values such as family, religion, solidarity and mutual. These values are related to the traditions of those countries [45].

An important area in research striving and business practices have been one of the ethical concerns in the field of management [50]. The above model shows the entrepreneur's behavior that is related to the ethical part as a common ground interacting with each of the capabilities around the center of this imaginary.

\section{International Entrepreneurial Capability}

International entrepreneurship is as one of the important stand researches in entrepreneurship on the role of organizational capabilities of the firm performance that has been induced and renewed [5,51-54]. International entrepreneurship literature has discussed the three major perspectives [18].

The first international entrepreneurship perspective underscores brokering, value creation, resource stretching or leveraging, and seeking the opportunity through a risk seeking behavior, proactive and combination of innovative.

Strategic management literature has been the origin of this perspective [55,56]. This prospective proponent has defined IE as a combination of risk-taking behavior, innovation, proactive and creation of the value in the firms on the cross-national borders [1].

International entrepreneurship as opportunities is the second perspective scenery. This viewpoint has defined it as the examination of how, by whom and the effects of opportunities to create future services and goods that are discovered then evaluated and exploited [57].

Entrepreneurship views in the third viewpoint are as a 
process of enactment and discovery. This perspective has not agreed with opportunities as objective phenomena. Proponents of this viewpoint believe the social milieu as a subjective phenomena creation influences among people [58]. Consequently, these three major perspectives have provided a base to conceptualize the capability of international entrepreneurship [18].

\subsection{The Dimensions of International Entrepreneurship Capability (IEC)}

\subsubsection{International Networking Capability (INC)}

International networking capability (INC) refers to the relation to counterparts in foreign networks, and the firms establish and develop their positions in international markets [59]. Networks and relationships as important factors have been mentioned and influenced on business improvement [60,61]. For instance, by relation to counterparts in foreign networks, the firms can establish and develop their positions in international markets [59]. Knowledge flow and exchange become possible by marketing connection and it foster communication between included groups, and establish a crucial channel for them [62,63].

Moreover, Investigators have theoretically recommended [64] and empirically observed [60,65] that network relationships enhance and expedite firm performance $[60,66]$. In order to understand firm's performance and behavior, some of the researchers have suggested that researches of business should shift a focus from traditional relationships to a business context of network relationships and this is an increasing need for the world of business research $[67,68]$.

On the other hand, one of the important entrepreneurial capabilities is international networking capability that mentions the company's capacity for acquiring a resource of wealth from surrounding by way of connection invention. Also, it involves the social insert for utilization of their performance into another country marketplace $[67,69]$. The capability of networking is more important than other strategies that chase after, by entrepreneurial companies. These firms acquire resources and get over environmental ambiguity and obstacles which can be important on the performance [70,71]. Viello [72] presented the concept of "network" as a simile that covers joint performers. These performers can be either persons or organizations, and they have the relationships that bind them jointly and capture large in number the forms. As an example, it can refer those among one who supplies products or services, customers, or government agencies. Networks of relationships as an important resource have extensively recognized in the literature of strategic management and international business that it can provide the competitive advantage by leveraging [73-
76]. Generally, international firms that acquire up-to-date knowledge to improve performance and nurture their relationships effectively, they are proactive in seeking network capabilities and often have a better chance of selecting reliable foreign partners $[77,78]$.

\subsubsection{International Marketing Capability (IMC)}

According to Song et al. [79], international marketing capability (EMC) comprises the rivalry of knowledge of client and ability in section to make groups of things a target market in pricing and advertising in merge market action. The capability to acquire knowledge, customer necessity and situation of their products in a successful manner, can be observed as an important determining factors of prosperity even for the small technology-based companies $[80,81]$. Technical ability in many cases is not sufficient, so a young firm need to learn the others skills [82]. For instance, the knowledge of marketing is a significant skill in existing understanding that is connected to the market.

The prior studies clarify international marketing capabilities that can be the firm's capacity to improve and perform the strategies of market, utilizing something that is known of rivalry to make exceptional value, by way of, necessary marketing components [83]. Marketing capabilities enable firms to tender production and provide assistance belonging to value purchasers fell to go beyond the potential value of alternative donation. It supplies the base from whichever the company that act on each other with the varied foreign marketplace [3]. At this point, globalizations is made easy to come out of buyers who are in a superior way arranged larger in quantity degree information, and ordinarily extra demanding [79].

Companies with potent international marketing capableness make particular marketing connected scheme aimed at get over these disputes and make as large as possible performance. Besides, it also enables firms to better study and realizes cline demands in order that they can hammer novel marketplace sections. Furthermore, international marketing keeps off commitment to incurrect ways. Hence, firms key out the "right" business situation nascent by potent marketing capableness in the procedure of internationalizations. Also they strongly plan commercial new angled products in the marketplace to catch inexperienced business chance [18].

Consequently, marketing capabilities have a key role to succeed in an accomplishment in the global markets [79]. It comprises the rivalry of knowledge of client and ability in orther to make groups of things a target market in pricing and advertising in merge market action. Furthermore, marketing capabilities are interested in the procedure of sales strategy evolvement and performance [84]. 


\subsubsection{Innovation and Risk-Taking Capability (IRC)} Innovation capability is the firm-level ability to manage technological innovation that can be the specific expert opinion and competence connected to the evolvement of the firms. Furthermore, it acts like an introducing to the new products or processes in the marketplace $[85,86]$. Initiation of the innovative project has been featured in small and young technology ventures by low investment and high uncertainty with risk-taking [87]. Information that is connected to resources has been fundamental to the success of innovation [88]. The creation of knowledge capability has been an essential predictor in the high-technology firms with an innovation outcome that is revealed by Smith, Collins et al. [89,90].

Innovation ability direct attention to the company's capacity that embrace different and modern innovative thoughts, productions, or procedure formulated to serve the international marketplace [91]. According to Bruyat and Julien [92] fundamentally, creativity is inherent in entrepreneurship to the scope that a lot of investigators seem to utilize the two sayings in an interchangeable manner. Risk-seeking ability mentions company's capability to tackle consequential and hazardous resource obligations in an international marketplace. Risk-taking conducts, as an example of acquiring heavily obligation in order to use occasions in the foreign markets probably to characterize in international entrepreneurial companies [91]. Therefore, inventive and risk-taking ability is nearly connected together [93]. There is a fact that a comprehensive exercise connects the two patterns in order to get the enterpriser manner of the firm [94]. The capabilities of technology affect on the success of innovation and it makes possible a firm to add value to processes and products. On the other hand, the success of innovation has a meaningful positive impact on the performance of organization [95].

\subsubsection{International Learning Capability (ILC)}

In the new ventures context, Autio et al. [54] has suggested that internationalizations may give to accelerate learning and capability reinforcement. Learning arguments to capability development have been extended by researchers through emphasizing a cumulative learning effect [54,96]. Organizational learning and experiential knowledge have been accepted as a principal strategic contrivance that differentiates firm performance. It has been argued in the international business literature [97]. In addition, for performance and survival, the importance of learning from failure has been studied and highlighted [98-100].

Every organization may develop to certain general capabilities and has a sure mixture of organizational learning capabilities (OLC) [101]. According to Di Bella et al. [102] organizational learning capabilities (OLC) have been defined as processes and construction of formal and informal situated properly for the acquirement, communion and utilizing of education and abilities in an organization. The abilities for self-expressing, programming and paying attention to environmental performance by scanning spread and shares knowledge to perform and test [103]. Moreover, dynamical abilities can be merged, created and configured differently. Capabilities speak of quickly altering environmental situation [104].

Assuming written above, international learning capabilities (ILC) can be define as a company's capability to obtain, participate and use its benefit and intelligent operations to make a scheme and disperse information. The literature of extending shows that the forms of the organizational learning are an important attribute of the culture of an organization that is connected to the organizational theory $[105,106]$. The importance of organizational learning in holding with marketplace necessity is emphasized by Bertels and Savage [107]. The versatile company would nurture learning average that makes strong its capacity to spread out in international marketplaces [93].

\subsubsection{International Experience (IE)}

Investigation in the formation of capability in start-ups has emphasized the founders' previous work experience role $[36,37,108]$. Furthermore, the cumulative effect of experience on the behavior of the firm has been emphasized by organizational learning literature [109-111]. In addition, on the speed of internationalizations, Management previous experience has affirmative influence [112].

On the other hand, the foremost dimension in international entrepreneurial capability is the international experience. It is important to determine the factor of time in internationalizations [113,114]. The born global scholars emphasize the operation in a worldwide economy. To do this, they need more importance international experiences that entrepreneurs habituated to use. Moreover, the born global theorists stated that the differences of older firms have formed by the impact of the education, international living and work experience of the founders [18, $115,116]$.

The psychic distance in particular markets reduce risk and ambiguity as much as possible that an be decreased by previous knowledge [115]. In addition, among countries, the previous activities of BG established companies caused the persons who decide to perform a significant function within expanding the companies to accelerate of making activities international [117]. To support this reasoning, according to Cohen and LEvinthal's [118] to absorb the capability of an idea, global born firms commence with fundamental knowledge regarding internationalizations. Therefore, BG's firms are further capable of gather modern education related to international activ- 
ity. If firms are be able to operate successfully in international markets; therefore, international experience gains should also develop the other capabilities of the firms [119].

\section{Conclusions}

This paper provides further information and evidence of the role of international entrepreneurship capability (IEC) on born global (BG) companies' performance through a review study of international entrepreneurship literature, capabilities and its dimensions. It explained and revealed the strong connection between the dimensions of international entrepreneurial capability (IEC) and international performance (IP) in born global (BG) firms. The study major contributions carried out are twofold. First, at the macro level, the proposal from a practical standpoint can be used by policymakers such as governmental planners and top managers whose plans play a significant role to make the entrepreneurial companies international. Secondly, at the micro level, this study can offer the managers of born global (BG) firms a comprehensive picture from international entrepreneurial capabilities (IEC) and supply valuable perceptions into how they can deal with dynamic international marketplaces. Therefore, it will be adequate that the international entrepreneurship capability to be introduced and presented in the local literatures in the industries and services that are internationalize their activities.

\section{REFERENCES}

[1] P. McDougall and B. Oviatt, "International Entrepreneurship: The Intersection of Two Research Paths,” Academy of Management Journal, Vol. 43, No. 5, 2000, pp. 902906. doi:10.2307/1556418

[2] M. M. Keupp and O. Gassmann, "The Past and the Future of International Entrepreneurship: A Review and Suggestions for Developing the Field,” Journal of Management, Vol. 35, No. 3, 2009, pp. 600-633. doi:10.1177/0149206308330558

[3] G. Knight and S. Cavusgil, "Innovation, Organizational Capabilities, and the Born-Global Firm,” Journal of International Business Studies, Vol. 35, No. 2, 2004, pp. 124142. doi:10.1057/palgrave.jibs.8400071

[4] K. Ohmae, “The Borderless World,” HarperCollins, New York, 1990.

[5] E. Autio, H. J. Sapienza and J. G. Almeida, "Effects of Age at Entry, Knowledge Intensity, and Imitability on International Growth,” The Academy of Management Journal, Vol. 43, No. 5, 2000, pp. 909-924. doi:10.2307/1556419

[6] S. A. Zahra, "A Theory of International New Ventures: A Decade of Research," Journal of International Business Studies, Vol. 36, No. 1, 2005, pp. 20-28. doi:10.1057/palgrave.jibs.8400118
[7] P. P. McDougall and B. Oviatt, "Toward a Theory of International New Ventures,” Journal of International Business Studies, Vol. 25, No. 1, 1994, pp. 45-64. doi:10.1057/palgrave.jibs.8490193

[8] M. Peng, "The Resource-Based View and International Business,” Journal of Management, Vol. 27, No. 6, 2001, p. 803. doi: $10.1177 / 014920630102700611$

[9] J. Lu and P. Beamish, "The Internationalization and Performance of SMEs,” Strategic Management Journal, Vol. 22, No. 6-7, 2001, pp. 565-586.

[10] B. Oviatt and P. McDougall, "A Framework for Understanding Accelerated International Entrepreneurship,” Research in Global Strategic Management, Vol. 7, No. 1, 1999, pp. 23-40.

[11] P. W. Beamish and N. C. Lupton, "Managing Joint Ventures," The Academy of Management Perspectives, Vol. 23, No. 2, 2009, pp. 75-94. doi:10.5465/AMP.2009.39985542

[12] M. Ruzzier, R. D. Hisrich and B. Antoncic, "SME Internationalization Research: Past, Present, and Future,” Journal of Small Business and Enterprise Development, Vol. 13, No. 4, 2006, pp. 476-497. doi:10.1108/14626000610705705

[13] Y. Yamakawa, M. W. Peng and D. L. Deeds, "What Drives New Ventures to Internationalize from Emerging to Developed Economies?” Entrepreneurship Theory and Practice, Vol. 32, No. 1, 2008, pp. 59-82. doi:10.1111/j.1540-6520.2007.00216.x

[14] H. J. Sapienza, et al., "A Capabilities Perspective on the Effects of Early Internationalization on Firm Survival and Growth,” The Academy of Management Review, Vol. 31, No. 4, 2006, pp. 914-933. doi:10.5465/AMR.2006.22527465

[15] S. H. Hymer, "The International Operations of National Firms: A Study of Direct Foreign Investment,” Stephen Herbert Hymer, Cambridge, 1976.

[16] S. Zaheer, "Overcoming the Liability of Foreignness," Academy of Management Journal, Vol. 38, No. 2, 1995, pp. 341-363. doi:10.2307/256683

[17] J. Yu, B. A. Gilbert and B. M. Oviatt, "Effects of Alliances, Time, and Network Cohesion on the Initiation of Foreign Sales by New Ventures," Strategic Management Journal, Vol. 32, No. 4, 2011, pp. 424-446. doi:10.1002/smj.884

[18] M. Zhang, P. Tansuhaj and J. McCullough, “International Entrepreneurial Capability: The Measurement and a Comparison between Born Global Firms and Traditional Exporters in China," Journal of International Entrepreneurship, Vol. 7, No. 4, 2009, pp. 292-322. doi:10.1007/s10843-009-0042-1

[19] P. Liesch, et al., "Born to Be Global,” A Research Project Undertook by Executive Summary and the university of Queensland business school, 2007.

[20] G. Knight, T. K. Madsen and P. Servais, “An Inquiry into Born-Global Firms in Europe and the USA,” International Marketing Review, Vol. 21, No. 6, 2004, pp. 645-665. doi:10.1108/02651330410568060

[21] D. Crick and M. V. Jones, "Small High-Technology Firms 
and International High-Technology Markets,” Journal of International Marketing, Vol. 8, No. 2, 2000, pp. 63-85. doi:10.1509/jimk.8.2.63.19623

[22] A. Aspelund, T. K. Madsen and O. Moen, “A Review of the Foundation, International Marketing Strategies, and Performance of International New Ventures,” European Journal of Marketing, Vol. 41, No. 11-12, 2007, pp. 14231448. doi:10.1108/03090560710821242

[23] S. Chetty and C. Campbell-Hunt, "A Strategic Approach to Internationalization: A Traditional versus a 'Born-Global' Approach,” Journal of International Marketing, Vol. 12, No. 1, 2004, pp. 57-81. doi:10.1509/jimk.12.1.57.25651

[24] R. Sembhi, "Capabilities Enabling Product Orientation and Service Orientation: A Study of Canadian Software Firms,” Ph.D. Thesis, University of Waterloo, Waterloo, 2010.

[25] R. Nelson and S. Winter, "Firm and Industry Response to Changed Market Conditions: An Evolutionary Approach,” Economic Inquiry, Vol. 18, No. 2, 1980, pp. 179-202. doi:10.1111/j.1465-7295.1980.tb00569.x

[26] R. Grant, "Prospering in Dynamically-Competitive Environments: Organizational Capability as Knowledge Integration,” Organization Science, Vol. 7, No. 4, 1996, pp. 375-387. doi:10.1287/orsc.7.4.375

[27] D. J. Teece, G. Pisano and A. Shuen, "Dynamic Capabilities and Strategic Management," Strategic Management Journal, Vol. 18, No. 7, 1997, pp. 509-533. doi:10.1002/(SICI)1097-0266(199708)18:7<509::AID-S MJ882>3.0.CO;2-Z

[28] C. Freeman and L. Soete, "The Economics of Industrial Innovation,” Routledge, London, 1997.

[29] B. Kogut and U. Zander, "Knowledge of the Firm, Combinative Capabilities, and the Replication of Technology," Organization Science, Vol. 3, No. 3, 1992, pp. 383-397. doi:10.1287/orsc.3.3.383

[30] G. Day, "The Capabilities of Market-Driven Organizations,” The Journal of Marketing, Vol. 58, No. 4, 1994, pp. 37-52.

[31] S. Winter, "The Satisficing Principle in Capability Learning,” Strategic Management Journal, Vol. 21, No. 10-11, 2000, pp. 981-996.

doi:10.1002/1097-0266(200010/11)21:10/11<981::AID-S MJ125>3.0.CO;2-4

[32] P. Schoemaker and R. Amit, "The Competitive Dynamics of Capabilities: Developing Strategic Assets for Multiple Futures,” John Wiley \& Sons Inc., New York, 1997.

[33] C. Prahalad and V. Ramaswamy, "Co-Opting Consumer Competence,” Harvard Business Review, Vol. 78, No. 1, 2000, pp. 79-93.

[34] J. Dyer and H. Singh, “The Relational View: Cooperative Strategy and Sources of Interorganizational Competitive Advantage," Academy of Management Review, Vol. 23, No. 4, 1998, pp. 660-679.

[35] J. Birkinshaw and P. Hagström, “The Flexible Firm: Capability Management in Network Organizations,” Administrative Science Quarterly, Vol. 46, No. 4, 2000, p. 230.

[36] R. Amit and P. Schoemaker, "Strategic Assets and Organizational Rent,” Strategic Management Journal, Vol.
14, No. 1, 1993, pp. 33-46. doi:10.1002/smj.4250140105

[37] C. E. Helfat and M. A. Peteraf, “The Dynamic Resource Based View: Capability Lifecycles,” Strategic Management Journal, Vol. 24, No. 10, 2003, pp. 997-1010. doi:10.1002/smj.332

[38] A. Krasnikov and S. Jayachandran, "The Relative Impact of Marketing, Research-and-Development and Operations Capabilities on Firm Performance,” Journal of Marketing, Vol. 72, No. 4, 2008, pp. 1-11. doi:10.1509/jmkg.72.4.1

[39] N. Karra, N. Phillips and P. Tracey, "Building the Born Global Firm: Developing Entrepreneurial Capabilities for International New Venture Success,” Long Range Planning, Vol. 41, No. 4, 2008, pp. 440-458. doi:10.1016/j.lrp.2008.05.002

[40] J. A. Timmons and S. Spinelli, "New Venture Creation: Entrepreneurship for the 21st Century,” Vol. 4, Irwin Burr Ridge, Burr Ridge, 1994.

[41] M. Wielemaker and E. Gedajlovic, "Governance and Capabilities: Asia’s Entrepreneurial Performance and Stock of Venture Forms," Asia Pacific Journal of Management, Vol. 28, No. 1, 2011, pp. 1-29.

[42] R. Makadok, "Toward a Synthesis of the Resource Based and Dynamic Capability Views of Rent Creation,” Strategic Management Journal, Vol. 22, No. 5, 2001, pp. 387401. doi:10.1002/smj.158

[43] J. Wiklund, et al., "The Future of Entrepreneurship Research," Entrepreneurship Theory and Practice, Vol. 35, No. 1, 2011, pp. 1-9. doi:10.1111/j.1540-6520.2010.00420.x

[44] S. Zahra and G. George, "International Entrepreneurship: The Current Status of the Field and Future Research Agenda," Strategic Entrepreneurship: Creating a New Mindset, Blackwell, London, 2002, pp. 255-288.

[45] L. Dana, "Handbook of Research on International Entrepreneurship,” Edward Elgar Publisher, Canterbury, 2006.

[46] C. J. Voisey, "When a Japanese Subsidiary Is Not a Japanese Subsidiary: Internationalization as Changing Organizational Identity and Capabilities," International Journal of Cross Cultural Management, Vol. 10, No. 2, 2010, p. 211. doi:10.1177/1470595810370915

[47] J. Woiceshyn and U. Daellenbach, "Integrative Capability and Technology Adoption: Evidence from Oil Firms," Industrial and Corporate Change, Vol. 14, No. 2, 2005, p. 307. doi:10.1093/icc/dth053

[48] T. S. Bateman and J. M. Crant, "The Proactive Component of Organizational Behavior: A Measure and Correlates,” Journal of Organizational Behavior, Vol. 14, No. 2, 1993, pp. 103-118. doi:10.1002/job.4030140202

[49] Marie, “L’Afrique des Individus,” Editions Karthala, Paris, 1997.

[50] G. Svensson and G. Wood, “A Conceptual Framework of Corporate and Business Ethics across Organizations: Structures, Processes and Performance,” The Learning Organization, Vol. 18, No. 1, 2011, pp. 21-35. doi:10.1108/09696471111095975

[51] M. Keupp and O. Gassmann, "The Past and the Future of International Entrepreneurship: A Review and Suggestions for Developing the Field,” Journal of Management, 
Vol. 35, No. 3, 2009, p. 600. doi:10.1177/0149206308330558

[52] G. A. Knight and S. T. Cavusgil, "Innovation, Organizational Capabilities and the Born-Global Firm,” Journal of International Business Studies, Vol. 35, No. 2, 2004, pp. 124-142. doi:10.1057/palgrave.jibs.8400071

[53] C. B. Bingham, "Oscillating Improvisation: How Entrepreneurial Firms Create Success in Foreign Market Entries Over Time,” Strategic Entrepreneurship Journal, Vol. 3, No. 4, 2009, pp. 321-345. doi:10.1002/sej.77

[54] E. Autio, G. George and O. Alexy, "International Entrepreneurship and Capability Development-Qualitative Evidence and Future Research Directions," Entrepreneurship Theory and Practice, Vol. 35, No. 1, 2011, pp. 11-37. doi:10.1111/j.1540-6520.2010.00421.x

[55] D. Miller, "The Correlates of Entrepreneurship in Three Types of Firms," Management Science, Vol. 29, No. 7, 1983, pp. 770-791. doi:10.1287/mnsc.29.7.770

[56] J. G. Covin and D. P. Slevin, "Strategic Management of Small Firms in Hostile and Benign Environments," Strategic Management Journal, Vol. 10, No. 1, 1989, pp. 7587. doi:10.1002/smj.4250100107

[57] S. Shane and S. Venkataraman, "The Promise of Entrepreneurship as a Field of Research," Academy of Management Review, Vol. 25, No. 1, 2000, pp. 217-226.

[58] T. Baker, E. Gedajlovic and M. Lubatkin, "A Framework for Comparing Entrepreneurship Processes across Nations,” Journal of International Business Studies, Vol. 36, No. 5, 2005, pp. 492-504.

doi:10.1057/palgrave.jibs.8400153

[59] T. Mainela and V. Puhakka, "Role of Networks in Emergence of International New Ventures," International Journal of Entrepreneurial Venturing, Vol. 3, No. 1, 2011, pp. 5-25. doi:10.1504/IJEV.2011.037855

[60] D. D. Sharma and A. Blomstermo, "The Internationalization Process of Born Globals: A Network View,” International Business Review, Vol. 12, No. 6, 2003, pp. 739-753. doi:10.1016/j.ibusrev.2003.05.002

[61] N. E. Coviello and H. J. Munro, "Growing the Entrepreneurial Firm: Networking for International Market Development," European Journal of Marketing, Vol. 29, No. 7, 1995, pp. 49-61. doi:10.1108/03090569510095008

[62] A. Larson, "Network Dyads in Entrepreneurial Settings: A Study of the Governance of Exchange Relationships," Administrative Science Quarterly, Vol. 37, No. 1, 1992, pp. 76-104. doi:10.2307/2393534

[63] H. L. Chen and Y. Huang, "The Establishment of Global Marketing Strategic Alliances by Small and Medium Enterprises,” Small Business Economics, Vol. 22, No. 5, 2004, pp. 365-377. doi:10.1023/B:SBEJ.0000022207.90510.46

[64] J. Johanson and J. E. Vahlne, “Commitment and Opportunity Development in the Internationalization Process: A Note on the Uppsala Internationalization Process Model,” Management International Review, Vol. 46, No. 2, 2006, pp. 165-178. doi:10.1007/s11575-006-0043-4

[65] H. Yli-Renko, E. Autio and V. Tontti, "Social Capital,
Knowledge, and the International Growth of TechnologyBased New Firms," International Business Review, Vol. 11, No. 3, 2002, pp. 279-304. doi:10.1016/S0969-5931(01)00061-0

[66] M. Han, "Developing Social Capital to Achieve Superior Internationalization: A Conceptual Model,” Journal of International Entrepreneurship, Vol. 4, No. 2, 2006, pp. 99112. doi:10.1007/s10843-007-0003-5

[67] R. Gulati, “Alliances and Networks,” Strategic Management Journal, Vol. 19, No. 4, 1998, pp. 293-317. doi:10.1002/(SICI)1097-0266(199804)19:4<293::AID-S MJ982>3.0.CO;2-M

[68] R. Achrol, "Changes in the Theory of Interorganizational Relations in Marketing: Toward a Network Paradigm," Journal of the Academy of Marketing Science, Vol. 25, No. 1, 1996, p. 56. doi:10.1177/0092070397251006

[69] M. Granovetter, "Economic Action and Social Structure: A Theory of Embeddedness," American Journal of Sociology, Vol. 91, No. 3, 1985, pp. 481-510. doi:10.1086/228311

[70] S. Alvarez and J. Barney, "How Entrepreneurial Firms Can Benefit from Alliances with Large Partners," The Academy of Management Executive (1993-2005), Vol. 15, No. 1, 2001, pp. 139-148.

[71] H. Steensma, et al., "The Influence of National Culture on the Formation of Technology Alliances by Entrepreneurial Firms," Academy of Management Journal, Vol. 43, No. 5, 2000, pp. 951-973. doi:10.2307/1556421

[72] N. E. Coviello, “The Network Dynamics of International New Ventures,” Journal of International Business Studies, Vol. 37, No. 5, 2006, pp. 713-731.

[73] H. Li and Y. Zhang, “The Role of Managers' Political Networking and Functional Experience in New Venture Performance: Evidence from China's Transition Economy,” Strategic Management Journal, Vol. 28, No. 8, 2007, pp. 791-804. doi:10.1002/smj.605

[74] M. Peng and Y. Luo, "Managerial Ties and Firm Performance in a Transition Economy: The Nature of a Micro-Macro Link,” Academy of Management Journal, Vol. 43, No. 3, 2000, pp. 486-501. doi:10.2307/1556406

[75] T. Chen, "Network Resources for Internationalization: The Case of Taiwan's Electronics Firms,” Journal of Management Studies, Vol. 40, No. 5, 2003, pp. 1107-1130. doi:10.1111/1467-6486.t01-1-00373

[76] J. Johanson and J. Vahlne, "Business Relationship Learning and Commitment in the Internationalization Process," Journal of International Entrepreneurship, Vol. 1, No. 1, 2003, pp. 83-101. doi:10.1023/A:1023219207042

[77] H. Hoang and B. Antoncic, "Network-Based Research in Entrepreneurship: A Critical Review," Journal of Business Venturing, Vol. 18, No. 2, 2003, pp. 165-187. doi:10.1016/S0883-9026(02)00081-2

[78] S. Harris and C. Wheeler, "Entrepreneurs' Relationships for Internationalization: Functions, Origins and Strategies,” International Business Review, Vol. 14, No. 2, 2005, pp. 187-207. doi:10.1016/j.ibusrev.2004.04.008

[79] M. Song, R. Nason and C. Di Benedetto, "Distinctive Marketing and Information Technology Capabilities and 
Strategic Types: A Cross-National Investigation,” Journal of International Marketing, Vol. 16, No. 1, 2008, pp. 4-38. doi:10.1509/jimk.16.1.4

[80] S. Zahra, R. Ireland and M. Hitt, "International Expansion by New Venture Firms: International Diversity, Mode of Market Entry, Technological Learning, and Performance,” Academy of Management Journal, Vol. 43, No. 5, 2000, pp. 925-950. doi:10.2307/1556420

[81] M. Brettel, A. Engelen and F. Heinemann, "New Entrepreneurial Ventures in a Globalized World: The Role of Market Orientation,” Journal of International Entrepreneurship, Vol. 7, No. 2, 2009, pp. 88-110. doi:10.1007/s10843-008-0033-7

[82] R. McGrath, I. Macmillan and S. Venkataraman, "Defining and Developing Competence: A Strategic Process Paradigm,” Strategic Management Journal, Vol. 16, No. 4, 1995, pp. 251-275. doi:10.1002/smj.4250160402

[83] S. Cavusgil and S. Zou, "Marketing Strategy-Performance Relationship: An Investigation of the Empirical Link in Export Market Ventures,” The Journal of Marketing, Vol. 58, No. 1, 1994, pp. 1-21.

[84] N. Morgan, D. Vorhies and C. Mason, "Market Orientation, Marketing Capabilities, and Firm Performance,” Strategic Management Journal, Vol. 30, No. 8, 2009, pp. 909-920. doi:10.1002/smj.764

[85] J. Hagedoorn and G. Duysters, "External Sources of Innovative Capabilities: The Preferences for Strategic Alliances or Mergers and Acquisitions," Journal of Management Studies, Vol. 39, No. 2, 2002, pp. 167-188. doi:10.1111/1467-6486.00287

[86] G. Ahuja, C. M. Lampert and V. Tandon, "Moving Beyond Schumpeter: Management Research on the Determinants of Technological Innovation,” The Academy of Management Annals, Vol. 2, No. 1, 2008, pp. 1-98. doi:10.1080/19416520802211446

[87] A. Bhide, "The Origin and Evolution of New Businesses,” Oxford University Press, New York, 2000.

[88] G. Verona, "A Resource-Based View of Product Development," Academy of Management Review, Vol. 24, No. 1, 1999, pp. 132-142.

[89] K. G. Smith, C. J. Collins and K. D. Clark, "Existing Knowledge, Knowledge Creation Capability, and the Rate of New Product Introduction in High-Technology Firms," The Academy of Management Journal, Vol. 48, No. 2, 2005, pp. 346-357. doi:10.5465/AMJ.2005.16928421

[90] N. E. Aaby and S. F. Slater, "Management Influences on Export Performance: A Review of the Empirical Literature 1978-1988," International Marketing Review, Vol. 6, No. 4, 1993, pp. 7-20.

[91] G. Lumpkin and G. Dess, "Clarifying the Entrepreneurial Orientation Construct and Linking It to Performance," Academy of Management Review, Vol. 21, No. 1, 1996, pp. 135-172.

[92] C. Bruyat and P. Julien, "Defining the Field of Research in Entrepreneurship,” Journal of Business Venturing, Vol. 16, No. 2, 2001, pp. 165-180. doi:10.1016/S0883-9026(99)00043-9

[93] S. Kitchell, “Corporate Culture, Environmental Adapta- tion, and Innovation Adoption: A Qualitative/Quantitative Approach,” Journal of the Academy of Marketing Science, Vol. 23, No. 3, 1995, pp. 195-205. doi:10.1177/0092070395233004

[94] S. A. Zahra, D. F. Jennings and D. F. Kuratko, "The Antecedents and Consequences of Firm-Level Entrepreneurship: The State of the Field,” Entrepreneurship Theory and Practice, Vol. 24, Part 2, 1999, pp. 45-66.

[95] S. Hao and B. Yu, "The Impact of Technology Selection on Innovation Success and Organizational Performance," iBusiness, Vol. 3, No. 4, 2011, pp. 366-371.

[96] G. George, "Learning to Be Capable: Patenting and Licensing at the Wisconsin Alumni Research Foundation 1925-2002,” Industrial and Corporate Change, Vol. 14, No. 1, 2005, p. 119. doi:10.1093/icc/dth046

[97] C. Hsu and A. Pereira, "Internationalization and Performance: The Moderating Effects of Organizational Learning," Omega, Vol. 36, No. 2, 2008, pp. 188-205. doi:10.1016/j.omega.2006.06.004

[98] A. S. Miner, et al., "Fruits of Failure: Organizational Failure and Population-Level Learning,” In: A. S. Miner, et al., Eds., Advances in Strategic Management, Vol. 16, 1999, pp. 187-220.

[99] P. R. Haunschild and B. N. Sullivan, "Learning from Complexity: Effects of Prior Accidents and Incidents on Airlines’ Learning," Administrative Science Quarterly, Vol. 47, No. 4, 2002, pp. 609-646. doi:10.2307/3094911

[100] A. C. Corbett, H. M. Neck and D. R. De Tienne, "How Corporate Entrepreneurs Learn from Fledgling Innovation Initiatives: Cognition and the Development of a Termination Script," Entrepreneurship Theory and Practice, Vol. 31, No. 6, 2007, pp. 829-852. doi:10.1111/j.1540-6520.2007.00208.x

[101] J. Bhatnagar, "Measuring Organizational Learning Capability in Indian Managers and Establishing Firm Performance Linkage: An Empirical Analysis,” The Learning Organization, Vol. 13, No. 5, 2006, pp. 416-433. doi:10.1108/09696470610679965

[102] A. DiBella, E. Nevis and J. Gould, "Understanding Organizational Learning Capability,” Journal of Management Studies, Vol. 33, No. 3, 1996, pp. 361-379. doi:10.1111/j.1467-6486.1996.tb00806.x

[103] Shukla, “The Learning Edge: Building Capabilities for Corporate Performance,” In: K. B. Akhilesh, L. Prasad and P. Singh, Eds., Evolving Performing Organizational through People, New Age International, New Delhi, 1995, pp. 209-214.

[104] V. García-Morales, F. Llorens-Montes and A. Verdú-Jover, "Antecedents and Consequences of Organizational Innovation and Organizational Learning in Entrepreneurship," Industrial Management \& Data Systems, Vol. 106, No. 1, 2006, pp. 21-42. doi:10.1108/02635570610642940

[105] Brown, “Organizational Culture,” Financial Times-Pitman, London, 1998.

[106] C. Moorman, "Organizational Market Information Processes: Cultural Antecedents and New Product Outcomes," Journal of Marketing Research, Vol. 32, No. 3, 1995, pp. 318-335. doi:10.2307/3151984 
[107] T. Bertels and C. Savage, "A Research Agenda for the Knowledge Era: The Tough Questions,” Knowledge and Process Management, Vol. 6, No. 4, 1999, pp. 205-212. doi:10.1002/(SICI)1099-1441(199912)6:4<205::AID-KP M67>3.0.CO;2-6

[108] C. E. Helfat and M. B. Lieberman, "The Birth of Capabilities: Market Entry and the Importance of Prehistory," Industrial and Corporate Change, Vol. 11, No. 4, 2002, p. 725.

[109] C. M. Fiol, "Consensus, Diversity, and Learning in Organizations,” Organization Science, Vol. 5, No. 3, 1994, pp. 403-420. doi:10.1287/orsc.5.3.403

[110] C. M. Beckman and P. R. Haunschild, "Network Learning: The Effects of Partners' Heterogeneity of Experience on Corporate Acquisitions,” Administrative Science Quarterly, Vol. 47, No. 1, 2002, pp. 92-124. doi:10.2307/3094892

[111] C. B. Bingham, K. M. Eisenhardt and N. R. Furr, "What Makes a Process a Capability? Heuristics, Strategy, and Effective Capture of Opportunities," Strategic Entrepreneurship Journal, Vol. 1, No. 1-2, 2007, pp. 27-47.

[112] B. M. Oviatt and P. P. McDougall, "Toward a Theory of International New Ventures,” Journal of International Business Studies, Vol. 25, No. 1, 1994, pp. 45-64. doi:10.1057/palgrave.jibs.8490193

[113] J. Johanson and J. Vahlne, "The Internationalization Process of the Firm-A Model of Knowledge Development and Increasing Foreign Market Commitments,” Jour- nal of International Business Studies, Vol. 8, No. 1, 1977, pp. 23-32. doi:10.1057/palgrave.jibs.8490676

[114] J. Johanson and J. E. Vahlne, "The Mechanism of Internationalisation,” International Marketing Review, Vol. 7, No. 4, 1993, pp. 11-24.

[115] T. Madsen and P. Servais, "The Internationalization of Born Globals: An Evolutionary Process?” International Business Review, Vol. 6, No. 6, 1997, pp. 561-583. doi:10.1016/S0969-5931(97)00032-2

[116] McKinsey Company and A. M. Council, "Emerging Exporters: Australia's High Value-Added Manufacturing Exporters: Final Report of the Study,” Australian Manufacturing Council, 1993.

[117] B. Oviatt and P. McDougall, “Challenges for Internationalization Process Theory: The Case of International New Ventures,” Management International Review, Vol. 37, No. 2, 1997, pp. 85-99.

[118] W. Cohen and D. Levinthal, "Absorptive Capacity: A New Perspective on Learning and Innovation,” Administrative Science Quarterly, Vol. 35, No. 1, 1990, pp. 128152. doi: $10.2307 / 2393553$

[119] S. Saarenketo, K. Puumalainen, O. Kuivalainen and K. Kyläheiko, “On Dynamic Knowledge-Related Learning Processes in Internationalizing High-Tech SME's," International Journal of Production Economics, Vol. 89, No. 3, 2004, pp. 363-379. doi:10.1016/S0925-5273(03)00185-3 